\title{
LOWER CRETACEOUS LIMESTONES FROM THE NORTHERN PART OF PĂDUREA CRAIULUI (OSOIU HILL AND SUBPIATRĂ SECTIONS): BIOSTRATIGRAPHY AND PRELIMINARY DATA ON MICROBIAL STRUCURES
}

\author{
HYAM DAOUD ${ }^{1}$, IOAN I. BUCUR ${ }^{1}$, EMANOIL SĂSĂRAN ${ }^{1}$ \& IOAN COCIUBA ${ }^{2}$
}

\begin{abstract}
Two sections have been measured within the Lower Cretaceous deposits from the northern part of Pădurea Craiului: Osoiu Hill section and Subpiatră section. Thin sections representing more than 180 samples allowed us to present some results on the biostratigraphy, facies succession and the role of microbial structures in the genesis of these limestones. The Osoiu Hill section is dominated by fenestral limestones formed in the intertidal or in the shallow subtidal zone. Their formation is dominantly related to microbial mats. Based on foraminiferal assemblages we attribute a Lower Barremian age to these limestones. The succession in the Subpiatra section is dominated by shallow facies with rudists, corals and Bacinella. These limestones contain Mesorbitolina texana a foraminifer which indicate Gargasian age. A more dense spectrum of microbial structures characterize this section: thrombolitic crusts, Bacinella-Lithocodium type structures, cryptic carbonate marine veneers and rivulariacean-like cyanobacteria. The microbial structures played an important role in the genesis of carbonate sediments and their lithification in the two sections.
\end{abstract}

Keywords: carbonate rocks, biostratigraphy, microbialites, microencrusters, Lower Cretaceous, Pădurea Craiului (Apuseni Mountains, Romania).

\section{INTRODUCTION}

This paper presents the preliminary results of our study on some carbonate deposits in the northern part of Pădurea Craiului massif, based on information provided by the measurement of two sections: Osoiu Hill (in the neighbourhood of Fâşca locality), and Subpiatră (located at about $2 \mathrm{Km}$ south from the "Holcim" quarry, in the place known as Fântâna Rece (Fig.1)

A general view of the succession of Cretaceous deposits of Pădurea Craiului was given by Patrulius (in lanovici et al., 1976). Additional contribution was provided by Dragastan et al. (1989), Bucur et al. (1993), Bucur \& Cociuba $(1996,1998)$, and Cociuba $(1999,2000)$. Establishing a clear stratigraphical succession of the Lower Cretaceous in Pădurea Craiului is not straightforward, as proven by the two main opinions expressed in the stratigraphical schemes elaborated by Dragastan et al. (1989) and Dragastan \& Ciobanu (2002) on the one hand, and by Bucur \& Cociuba (1988), Cociuba (1999, 2000), Bucur (2000) and Bucur \& Cociuba (2001) on the other. The current paper adopted the latter point of view.

\footnotetext{
1 Babeş-Bolyai University, Department of Geology, str. M. Kogălniceanu nr.1, 400084 Cluj-Napoca, Romania.E-mails: dhyam12@yahoo.com; ibucur@bioge.ubbcluj.ro; esasaran@bioge.ubbcluj.ro

${ }^{2}$ Geological Institute of Romania, Cluj branch, C.P. E-mail: ioan_cociuba@yahoo.com
} 


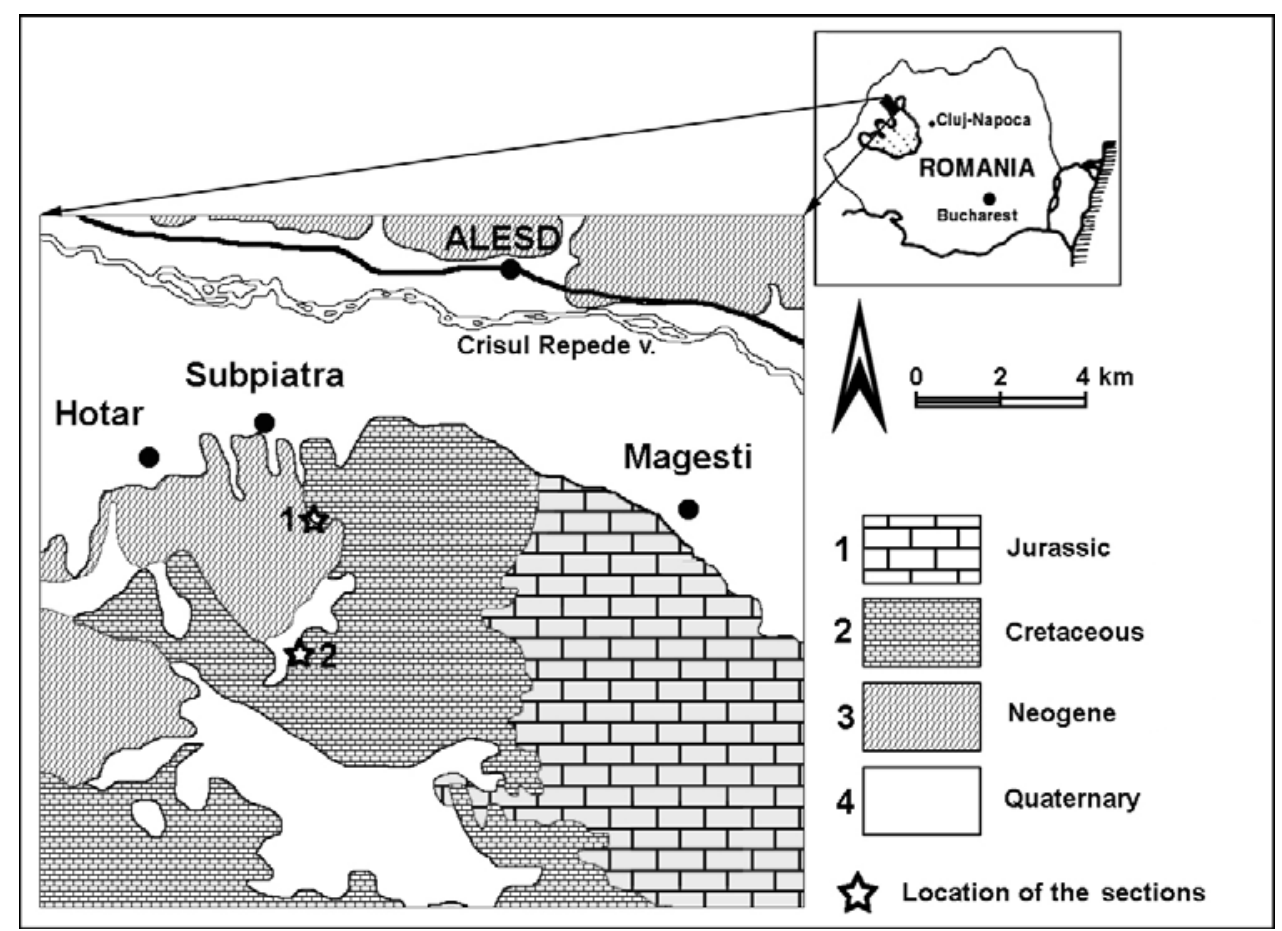

Fig. 1 - Location of the studied area, with emplacement of the two sections:

Subpiatra (1) and Osoiu Hill (2)

\section{SUCCESSION AND BIOSTRATIGRAPHIC REMARKS}

\section{Osoiu Hill Section}

This section has been measured along $87 \mathrm{~m}$ thickness (Fig. 2). A total number of 83 samples has been collected, which have been investigated in thin sections.

The succession is dominated by fenestral limestones basically formed in the intertidal (the lower part of the succession), or in the shallow subtidal zone (the middle part of the succession). The upper part mainly consists of micrites, often of a fenestral and laminitic type.

The intertidal facies are represented by: peloidal fenestrate grainstone, fenestral grainstone/packstone, laminated wackestone/packstone, fenestral wackestone, mudstone/wackestone and fenestral mudstone. Peloids are abundant, Sometimes also micritic intraclasts are present. Bioclasts are represented by miliolids and other small foraminifers, ostracods, fragments of gastropods and rare fragments of bivalves (rudists). Rivulariacean-type cyanobacteria are present but not abundant. The fenestral lamination, the geopetal sediment, the meniscus- and stalactitic-type cement represent the specific features of these deposits.

The shallow subtidal facies are represented by Bacinella bindstone and wackestone/packstone with foraminifers and algae. Ostracod rests, fragments of bivalves and gastropods, as well as frequent rivulariacean-type cyanobacteria were also noticed. 


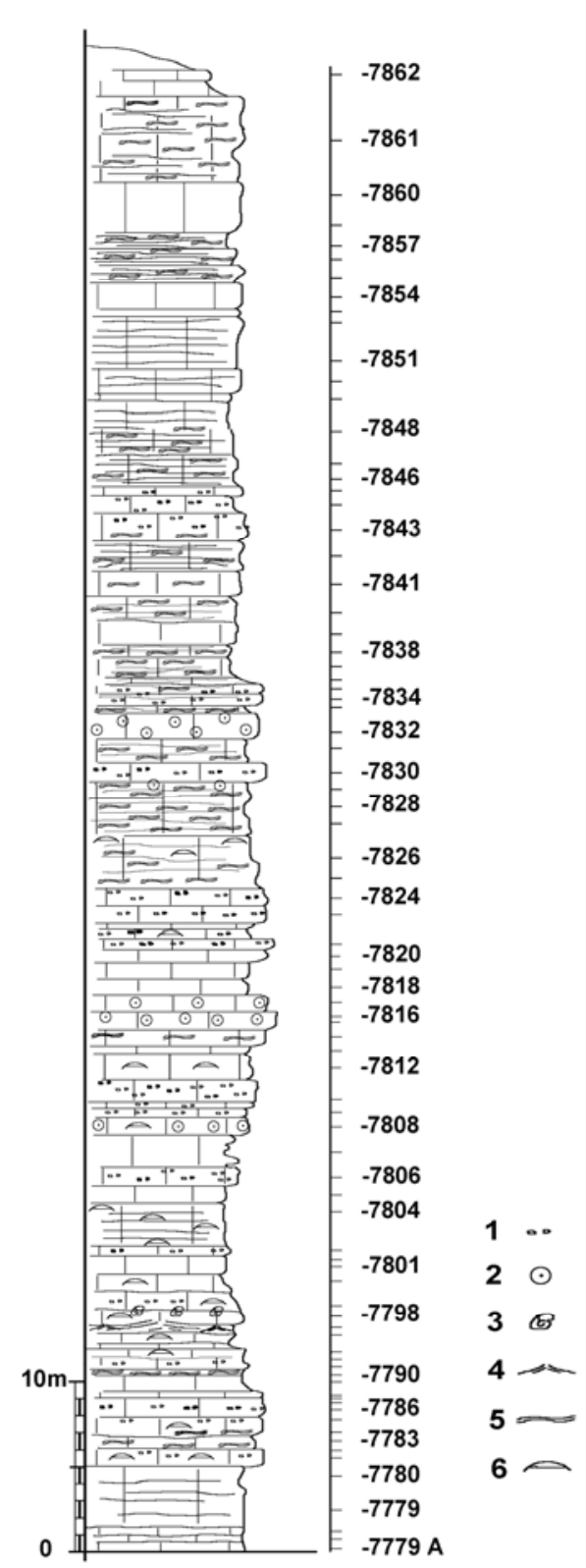

Fig. 2 - Osoiu Hill section. 1 - grains (ooids excepted); 2 - ooids; 3 - gastropods; 4 - tepee structures; 5 - laminitic structures; 6 - fenestral structures.
The ooids are common components in these limestone, leading to ooidic grainstone sequences often overlaying the sediments in their base along erosional surfaces (PI.III, figs. 2, 5; PI.IV). The high hydrodynamic regime often resulted in the formation of brecciated structures (PI.III, fig.4). The fenestral (PI.III, figs. 1-3) and laminitic (PI.III, fig.5; pl.IV) structures prove the interference of the shallow subtidal facies with the intertidal ones.

The micrites in the top of the succession mainly contain rivulariaceantype cyanobacteria, small foraminifers, ostracods and rare fragments of gastropods. The deposits often show fenestral and laminitic structures; they were probably formed at the border within the shallow subtidal and intertidal zones.

A relatively scarce micropaleontological association was found within the whole succession. The following dasyclad algae and foraminifers have been identified: Salpingoporella muehlbergii (LORENZ), Falsolikanella danilovae (RADOIČIĆ), Clypeina sp., Actinoporella sp., Paracoskinolina? jourdanensis (FOURY \& MOULLADE) (PI.III, figs.7-8), Pseudolituonella gavonensis FOURY, Pfenderina globosa FOURY (PI.III, fig.6), ?Earlandia sp., Charentia sp., Vercorsella sp., Belorusiella sp., Patellovalvulina sp., and Dobrogelina sp.

Based on the association with Paracoskinolina? jourdanensis, Pfenderina globosa and Pseudolituonella gavonensis (Foury \& Moullade, 1966; Foury, 1968; Arnaud-Vanneau, 1980), we attribute a Lower Barremian age to these limestones. They correspond to the middle part of the Coposeni Member within the Blid Formation (sensu Cociuba, 2000). 


\section{Subpiatră Section}

The section was measured along 120 m thickness. A total of 99 samples were collected and studied in thin section. In its lower third, the succession is interrupted by a fault. For studying the deposits developed above the fault, two distinctive successions ( $A$ and $B$ ) located at a lateral distance of $20-30 \mathrm{~m}$ one from each other, have been measured (Fig.3).

The succession is dominated by shallow facies with rudists, corals and Bacinella. The lower part, the first $45 \mathrm{~m}$ above the base, mainly consists of rudist boundstone and Bacinella bindstone. Besides, foraminifers (orbitolinids, encrusting foraminifers, miliolids and other small benthic foraminifers), fragments of corals, gastropods and echinids, ostracods, rare dasyclads and rivulariacean-type cyanobacteria are present.

Associated to the two dominating facies types, are peloidal-fenestral grainstone, packstone and packstone/grainstone, coarse grainstone with fragments of rudists or with orbitolinids. The bioclasts are generally the same: fragments of rudists, gastropods, echinoderms, corals, rare ostracods, foraminifers (mainly orbitolinids, miliolids and encrusting foraminifers). Dasyclads are more frequent in the granularbioclastic varieties, being accompanied by red algae (Solenoporaceans and Peyssonneliaceans). Rivulariacean-like cyanobacteria are a less abundant, but omnipresent component.

The middle part of the succession (of about $40 \mathrm{~m}$ length) is dominated by coarse grainstone and bioclastic packstone/grainstone with fragments of corals and rudists, gastropods, echinoderm debris, orbitolinids and rare dasyclads. Part of this succession, about $15-20 \mathrm{~m}$ length, is dominated by the two facies, rudist boundstone and Bacinella bindstone. Coral boundstones occur at several levels. Frequently, besides Bacinella also Lithocodium is present. Rivulariacean-type cyanobacteria, even if in small amounts occur constanly, in a similar pattern as in the lower part of the succession.

Finally, the upper part of the succession, on a length of about $30-35 \mathrm{~m}$, consists of bioclastic grainstone/packstone, with the relatively frequent orbitolinids starting to agglutinate sponge spicules. The orbitolinids are associated by encrusting foraminifers, solenoporacean red algae (Marinella) and rare fragments of dasyclads, Lithocodium nodules, fragments of rudists, worm tubes and abundant, small fragments of echinoderms. All these features point to a deepening trend of the depositional environment (slope, or upper slope facies). The presence of several coral boundstone levels indicate specific trends of the environment's evolution towards the platform border. Such a level allows the lateral correlation of the deposits in the two complementary sections (Fig.3).

The micropaleontological association in the Subpiatră section consists of the following calcareous algae and foraminifers: Bakalovaella elitzae (BAKALOVA) (PI.I, fig.3), Salpingoporella cf. patruliusi (BUCUR) (PI.I, fig.5), Salpingoporella sp., Neomeris sp. (PI.I, fig. 4), Polystrata alba (PFENDER), Marinella lugeoni PFENDER, Giraliarella? prismatica ARNAUD-VANNEAU, Sabaudia minuta (HOFKER) (PI.I, fig.2), Mesorbitolina texana (ROEMER) (PI.I, fig.1), Troglotella incrustans Wernli \& FOOKES (PI.II, fig.4), Everticyclammina sp., Vercorsella sp., Novalesia sp., Voloshinoides sp., Charentia sp., Mayncina sp., Nautiloculina sp., Dobrogelina sp., Meandrospira sp., and Orbitolinopsis sp. The microproblematic Coptocampylodon fontis (PATRULIUS) (PI.I, fig.5) was also identified in this association. 
A

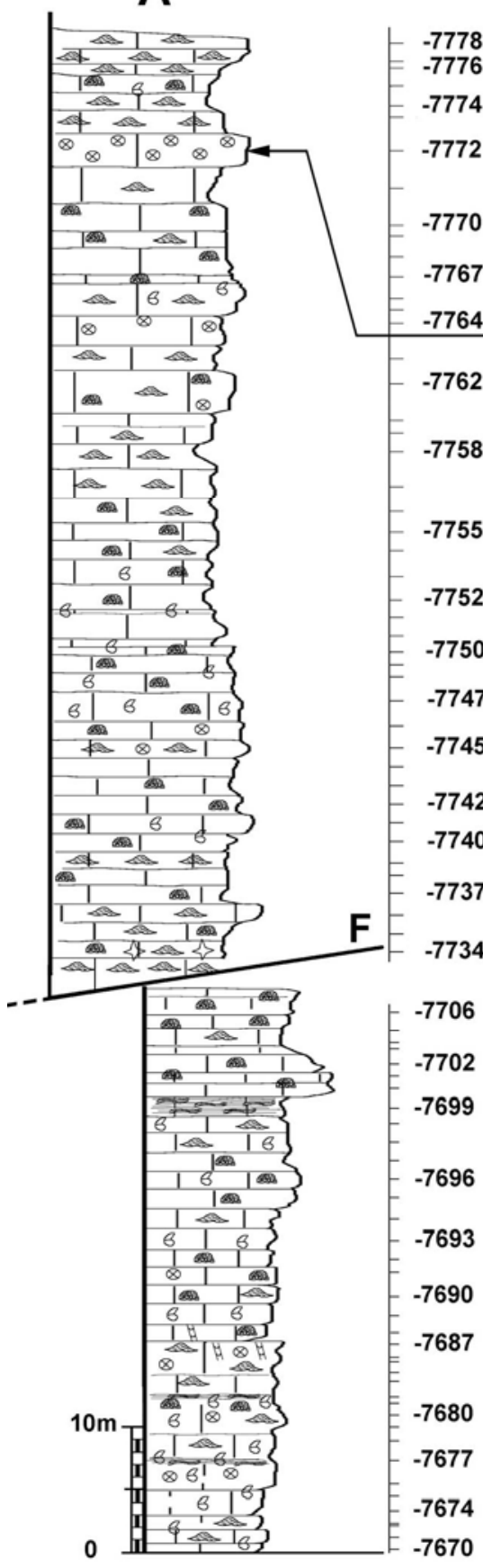

B

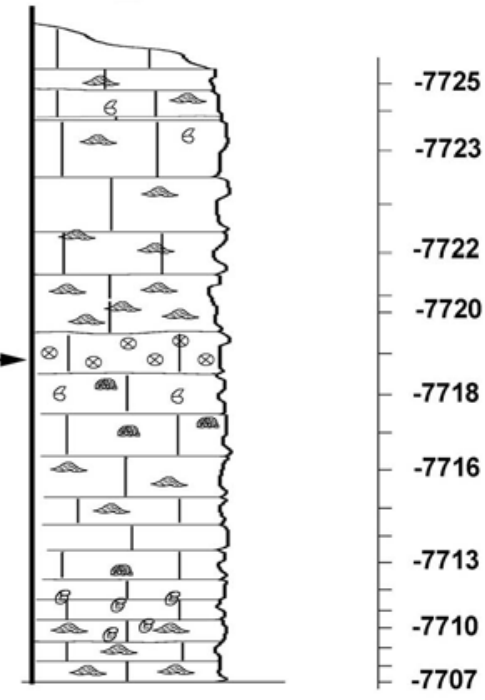

Fig. 3 - Subpiatra section

$1 \& \quad$ - rudists

2 - Bacinella

$3 \leftrightarrow$ - orbitolinids

4 i - dasyclads

$5 \otimes$-corals

$6 \curvearrowright$-echinoderms

7 \& -gastropods

$8=-$ laminitic structures 
The presence of Mesorbitolina texana is a clear indicator that the deposits can not be older then the Gargasian. According to the adopted stratigraphical scheme of the Pădurea Craiului region (Cociuba, 2000), carbonate deposits of this age are known within the Vârciorog Formation, being previously attributed to the so-called "Upper Pachyodont Limestones" (fide Patrulius, in lanovici et al., 1976). It is worth to mention that in the type-section of the Vârciorog Formations these limestones are not more than $15-20 \mathrm{~m}$ in thickness, while in the Subpiată section they are $120 \mathrm{~m}$ thick. Taking into account also the allochthonous feature of the corresponding deposits at Vârciorog - resembling slope-flows towards deeper basin areas, we consider that the Subpiatră section preserves in situ the platform which had generated the flows. Additional research is needed for defining the detailed configuration of this platform.

\section{PRELIMINARY REMARKS ON MICROBIAL STRUCTURES}

As proven by numerous studies (e.g. Leinfelder et al., 1993; Schmid, 1996; Helm \& Schülke, 1998; Dupraz \& Strasser, 1999; Ouribane et al., 2000; Schlagintweit \& Gawlik, 2003), microbialites have played a significant role during Jurassic especially the Upper Jurassic - in the Tethysian area; sometimes they lead to the formation of microbialitic reefs proper. On the contrary, very little information on the deposits of microbial origin of the Lower Cretaceous is available: e.g. Masse $(1969,1972,1979)$ has described deposits and structures basically of microbial origin as "cryptalgal structures"; Neuweiller (1993) studied Albian microbialites from Spain.

Even if currently no microbial reefs have been discovered in the Lower Cretaceous limestones, it is obvious the microbialites and microencrusters have played a significant role during this interval as well (as indicated by the structures described in Urgonian deposits by Masse, 1969, 1979).

The two sections investigated in the present paper characterise two distinctive sedimentation domains, each including microbial structures but showing specific features.

\section{Osoiu Hill Section}

The formation of the limestones in Osoiu Hill, in the intertidal zone, is dominantly related to microbial mats, the process being followed by desiccation and lithification that lead to the fenestral-laminitic character (PI.III, figs.1, 3; PI.IV). The increase of hydrodynamic energy often resulted in the "burial" of the microbial mats by granular sediments along erosional surfaces (PI.III, fig.2; PI.IV). Besides the microbial mats, assumed to represent the main microbial-related structures in these limestones, some other structures of secondary importance have been identified. For example, some larger intraclasts formed as a result of the break of the penecontemporaneous sediment, have been subsequently surrounded by small-sized thrombolitic crusts. Similarly, some microbialitic oncoids are sometimes associated with microbial mats. Rivulariacean-type cyanobacteria are present along the whole succession, Bacinella bindstone being scarce. 


\section{Subpiatră Section}

A more diverse spectrum of microbial structures (including microencrusters) characterize this section. The rudist boundstone frequently contains microbialitic crusts binding the rudist skeletons (PI.II, fig. 5). They are often associated with micritic peloids of microbial nature and with a fenestral-type microbialitic sediment developed inside the rudist tests. Such microbial crusts most probably were formed soon after the sediment burial, when the rudist skeletons have been surrounded by microbial colonies that also are assumed to have caused the endolithic perforations (PI.II, fig.5) in the rudists' tests (Neuweiller, 1993).

Coral boundstones are often covered by thrombolitic crusts with a relatively limited extent. Sometimes the coral interseptal(?) spaces were post mortem invaded by tubular cyanobacteria (PI.II, fig.3).

However, in the Subpiatră section the largest extent belongs to the Bacinellatype structures (PI.II, fig.1). They consist of massif banks with the voids of the Bacinella network embedded in micritic peloids and various types of bioclasts. Bacinella is also the main structure type that binds the bivalve tests within some rudist boundstones. In some case it is associated with Lithocodium-type structures and with the foraminifer Troglotella, the latter producing perforations in the rudist skeletons (PI.II, fig.4). Camoin \& Maurin (1988) consider bacinelloid structures as microbial products, this being reinforced by Uță \& Bucur (2003). According to Neuweiller (1992), Bacinella (bacinelloid Lithocodium in the terminology of Neuweiller) together with other algae and microbes "is a major constituent of thrombolitic mud mounds". Neuweiller described massive $(8 \mathrm{~m})$ bacinelloid Lithocodium boundstones in Albian deposits in Spain, demonstrating its role in baffling and binding, and underlining the major contribution in the micrite production.

A special type of microbial structures occurring in the limestones of the Subpiatră section is represented by the micritic structures formed inside the rudist skeletons (PI.II, fig.2); it closely resembles the "cryptic carbonate marine veneers" described by Riding (2002).

The encrusting foraminifers are many times associated with Bacinella/ Lithocodium (PI.I, fig.7), or with "Tubiphytes"-type structures (PI.I, fig.8) in the frame of crusts that have played a role during the sediment lithification. Finally, another case are the rivulariacean-type cyanobacteria (PI.I, fig.6), which even if in small amounts occur constantly along the whole succession.

\section{CONCLUSIONS}

The study of two measured sections within the Lower Cretaceous limestones in the northern part of Pădurea Craiului has shown that these deposits belong to 1) Lower Barremian (Osoiu Hill section) with Paracoskinolina? jourdanensis, and 2) Upper Aptian (Gargasian) (Subpiatră section) with Mesorbitolina texana.

The microbial structures (microbial mats, thrombolitic microbialites, diverse types of microbial crusts and microencrusters) have been identified in both sections, as contributors to the sediment formation (mainly via the microbial mats, in the case of the intertidal limestones from Osoiu Hill, and via the Bacinella bindstone in the Subpiatră section), but also as factors of the carbonate sediments' consolidation and cementation in both sections. 
HYAM DAOUD, IOAN I. BUCUR, EMANOIL SĂSĂRAN, IOAN COCIUBA

\section{Acknowledgements}

This paper represents a contribution to the research project on "Microbialites in the Mesozoic and Tertiary deposits of Romania" (I.I. Bucur) financed by Grant 1690 CNCSIS. We thank our colleague, Dr. Dana Pop, for the English translation and Dr. Steve Kershaw for his review which lead to improvement of the text.

\section{REFERENCES}

Bucur, I.I., 2000, Lower Cretaceous dasyclad algae from the Pădurea Craiului massif (Northern Apuseni Mountains, Romania). In: Bucur I.I. \& Filipescu S. (eds.) - Acta Palaeontologica Romaniae 2 (1999), p.53-72, Cluj University Press, Cluj-Napoca.

Bucur, I.I. \& Cociuba, I., 1996, Microbiostratigraphic markers in the Lower Cretaceous deposits from Pădurea Craiului (Northern Apuseni Mountains). - Anuarul Institutului Geologic al României, 69, supplement 1 (The 90-th Aniversary Conference of the Geological Institute of Romania, June 12-19, 1996), Abstracts, p.40-43, Bucureşti.

Bucur, I.I. \& Cociuba, I., 1998, La plate-forme carbonatée du Crétacé inférieur des Monts Pădurea Craiului (Monts Apuseni, Roumanie). Biostratigraphie et configuration. Studia Universitatis Babeş-Bolyai, Geologia, XLIII/2, p.89-100, Cluj-Napoca.

Bucur, I.I. \& Cociuba, I., 2001, Upper Jurassic-Lower Cretaceous deposits from Pădurea Craiului. In: Bucur I.I., Filipescu S. \& Săsăran E. (eds.) - Algae and carbonate platforms in the western part of Romania $4^{\text {th }}$ Regional Meeting of IFAA, Cluj-Napoca, Romania, August 29-September 5, 2001, Field trip Guide Book), p.43-52, Cluj University Press, Cluj-Napoca.

Bucur, I.I., Cociuba, I. \& Cociuba, M., 1993, Microfacies and microfossils in the Upper JurassicLower Cretaceous limestones in the southern part of the Pădurea Craiului Mountains. Romanian Journal of Stratigraphy, 75, p.33-40, Bucureşti.

Camoin, G \& Maurin, A-F., 1988, Rôle des micro-organismes (bactéries, cyanobactéries) dans la genèse des "Mud Mounds". Exemple du Turonien des Jebels Bireno et Mrhila (Tunisie). C.R. Acad. Sci., 307/4, p.401-407, Paris.

Cociuba, I., 1999, Studiul stratigrafic al depozitelor mezozoice din sud-vestul Pădurii Craiului. Unpublished PhD Thesis, University Babeş-Bolyai, 253 p., Cluj-Napoca.

Cociuba, I. 2000, Upper Jurassic-Lower Cretaceous deposits in the soth-western part of Pădurea Craiului. Formal lithostratigraphic units. Studia Universitatis Babeş-Bolyai, Geologia, XLV/2, p.33-61, Cluj-Napoca.

Dragastan, O., Marinescu, M., Gheorghe, D. \& Tinteanu, C., 1989, Upper Bauxite sensu D. Patrulius and some new algae of Pădurea Craiului Mts. (Northern Apuseni). Revue Roumanine de Géologie, Géophysique et Géographie, Géologie, 33, p.55-67, Bucureşti.

Dragastan, O. N. \& Ciobanu, C., 2002, New calcareous algae (Bryopsidophyceae) from the Blid Formation (Berriasian-Early Aptian) of the Sothern Brusturi sector (Apuseni Mts.) and some new litho- and biostratigraphical data. In Baciu I., Bucur I.I., Filipescu S. and Săsăran E. (eds.) Studia Universitatis Babeş-Bolyai, Geologia, Special issue 1, p.165-188, Cluj-Napoca

Dupraz, C. \& Strasser, A., 1999, Microbialites and micro-encrusters in shallow coral bioherms (Middle to Late Oxfordian, Swiss Jura Mountains). Facies, 40, p.101-130, Erlangen.

Helm, C. \& Schülke, I., 1998, A coral-microbialite patch reef from the Late Jurassic (florigemmabank, Oxfordian) of NW Germany (Süntel Mountains). Facies, 39, p.75-104, Erlangen.

lanovici, V., Borcoş, M., Bleahu, M., Patrulius, D., Lupu, M., Dimitrescu, R. \& Savu, H., 1976, 
Geologia Munților Apuseni. Ed. Acad. RSR, 631 p., Bucureşti.

Leinfelder, R.R., Nose, M., Schmid, D.U. \& Werner, W., 1993 Microbial crusts of the Late Jurassic: composition, palaeoecological significance and importance in reef construction. Facies, 29, p.38-42, Erlangen.

Masse, J.P., 1969, Présence de structures à affinités stromatolitiques dans l'Urgonien des îles du Frioul (rade de Marseille, B.-du-Rh.). Bulletin de la Société de géologie de France (7), XXI, p.128-132, Paris.

Masse, J. P., 1972, Structures cryptalgaires libres dans un complexe carbonaté de plate-forme: les calcaires urgoniens (Barrémien) de Provence (Sud-Est de la France). 24th IGC, Section 7, p.572-585, Paris.

Masse, J. P., 1979, Schizophytoïdes du Crétacé inférieur. Caractéristiques et signification écologique. Bull. Centr. Rech. Explor.-Prod. Elf-Aquitaine, 3/2, p.686-703, Pau.

Neuweiller, F. \& Reitner, J., 1992, Karbonatbänke mit Lithocodium aggregatum Elliott/Bacinella irregularis Radoicic. Berliner geowissenschaften Abhandlungen (E), 3, p.273-293, Berlin.

Neuweiller, F., 1993, Development of Albian microbialites and microbialite reefs at marginal platform area of the Vasco-Cantabrian Basin (Soba reef area, Cantabria, N. Spain). Facies, 29, p.231-250, Erlangen.

Ourribane, M., Chellai, E.H. \& Zaghbib-Turki, D., 2000, Rôle des microbialites et des "microencroûtants" dans la lithification récifale: exemples du Jurassique supérieur de l'Atlas maghrébin (Maroc et Tunisie). C.R. Acad. Sci Paris, Sciences de la Terre et des planetes, 330, p.407-414, Paris

Riding, R., 2000, Biofilm architecture of Phanerozoic cryptic carbonate marine veneers. Geology, 30/1, p.31-34, Washington.

Schmid, D. U., 1996, Marine microbolithe und Mikroinkrustierer aus dem Oberjura. Profil, 9, p. 101 251, Stuttgart.

Schlagintweit, F. \& Gawlick, H.-J., 2003, Mikrobolithe und Mikroinkrustierer aus der Plassen_ Formation (Kimmeridgium-Berriasium) der nördlichen Kalkalpen. In: Weidinger J.T., Lobitzer H. \& Spitzbart I. (eds.) - Beiträge zur Geologie des Salzkammerguts, Gmundner GeoStudien 2, p. 107-114, Gmunden.

Uță, A. \& Bucur, I.I., 2003, Microbial structures and microencrusters in the Upper Jurassic-Lower Cretaceous deposits from Buila-Vânturarița Massif (South Carpathians). Sudia Universitatis Babeş-Bolyai, Geologia, XLVIII/2, p.3-14, Cluj-Napoca.

\section{PLATES}

\section{Plate I}

Fig. 1 - Mesorbitolina texana (ROEMER). Longitudinal section passing through the embryonic apparatus. Sample 7683 (Subpiatră section), x 60.

Fig. 2 - Sabaudia minuta (HOFKER). Longitudinal-tangential section cutting the embryonic apparatus. Sample 7738 (Subpiatră section), x 60.

Fig. 3 - Bakalovaella elitzae (BAKALOVA). Oblique section. Sample 7684 (Subpiatră section), $\times 30$.

Fig. 4 - Neomeris sp. Sample 7804 (Subpiatră section), x 60

Fig. 5 - Salpingoporella cf. patruliusi BUCUR (fragment in oblique section), and Coptocampylodon fontis PATRULIUS (several transverse sections). Sample 7685 (Subpiatră section), x 30.

Fig. 6 - Rivulariacean-type cyanobacteria. Sample 7691 (Subpiatră section), x 30. 
HYAM DAOUD, IOAN I. BUCUR, EMANOIL SĂSĂRAN, IOAN COCIUBA

Fig. 7 - Bacinella irregularis RADOIČIĆ and Lithocodium aggregatum ELLIOTT, encrusted by a pseudoalveolar foraminifer. Sample 7676 (Subpiatră section), x 30.

Fig. 8 - Agglutinated foraminifer encrusted by "Tubiphytes" and micritic microbial crusts. Sample 7686 (Subpiatră section), x 30.

\section{Plate II}

Fig. 1 - Bacinella irregularis RADOIČIĆ. Sample 7689 (Subpiatră section), x 15.

Fig. 2 - Micrite of microbial origin formed inside and outside of a rudist skeleton. Sample 7673 (Subpiatră section), x 15.

Fig. 3 - Tubular cyanobacteria in a coral fragments. Sample 7707 (Subpiatră section), x 60.

Fig. 4 - Rudist skeleton perforated by Troglotella incrustans WERNLI \& FOOKES hosted by Bacinella-Lithocodium. Sample 7705 (Subpiatră section), x 15.

Fig. 5 - Rudist fragment covered by microbial micrite. Note also the endolithic perforations of the bivalve shell field with the same type of micrite surrounding the shell. Sample 7712 (Subpiatră section), x 15.

Fig. 6 - Pfenderina globosa FOURY. Transverse-oblique section. Sample 7780 (Osoiu Hill section), $x 60$.

Fig. 7-8 - Paracoskinolina ? jourdanensis FOURY \& MOULLADE. Longitudinal (7) and transverse (8) sections. Sample 7806 (Osoiu Hill section), $\times 30$.

Plate III

Fig. 1 - Fenestral limestone with micritic and peloidal deposit inside fenestrae. Sample 7829 (Osoiu Hill section), x 7,5.

Fig. 2 - Laminae of peloidal fenestrate grainstone with large micritic oncoids, separated by irregular micritic crusts. Sample 7832A (Osoiu Hill section), x 10.

Fig. 3 - Peloidal fenestrate micrite (fenestral microbial mat). Note the stalactitic cement, and the stalactitic microbial veneers on the roof of fenestrae. Sample 7847 (Osoiu Hill section), x 20.

Fig. 4 - Microbreccia in a micritic-peloidal fenestrate limestone. Sample 7829 (Osoiu Hill section), $\times 20$.

Fig. 5 - Laminitic sequence with fine micritic laminae in the lower part, followed by coarser lamiane of peloidal grainstone. Sample 7833 (Osoiu Hill section), $x$ 7,5 .

Fig. 6 - Flat-pebbles microbreccia in a supratidal laminitic limestone. Sample 7834 (Osoiu Hill section), x 7,5.

Plate IV

Fig. 1 - Intertidal-supratidal small cycle: upper intertidal-lower supratidal peloidal fenestrate mud (microbial mat) eroded by small intertidal channel field with peloidalooidic sediment. Sample 7832B (Osoiu Hill section), x 7,5. 
Plate I
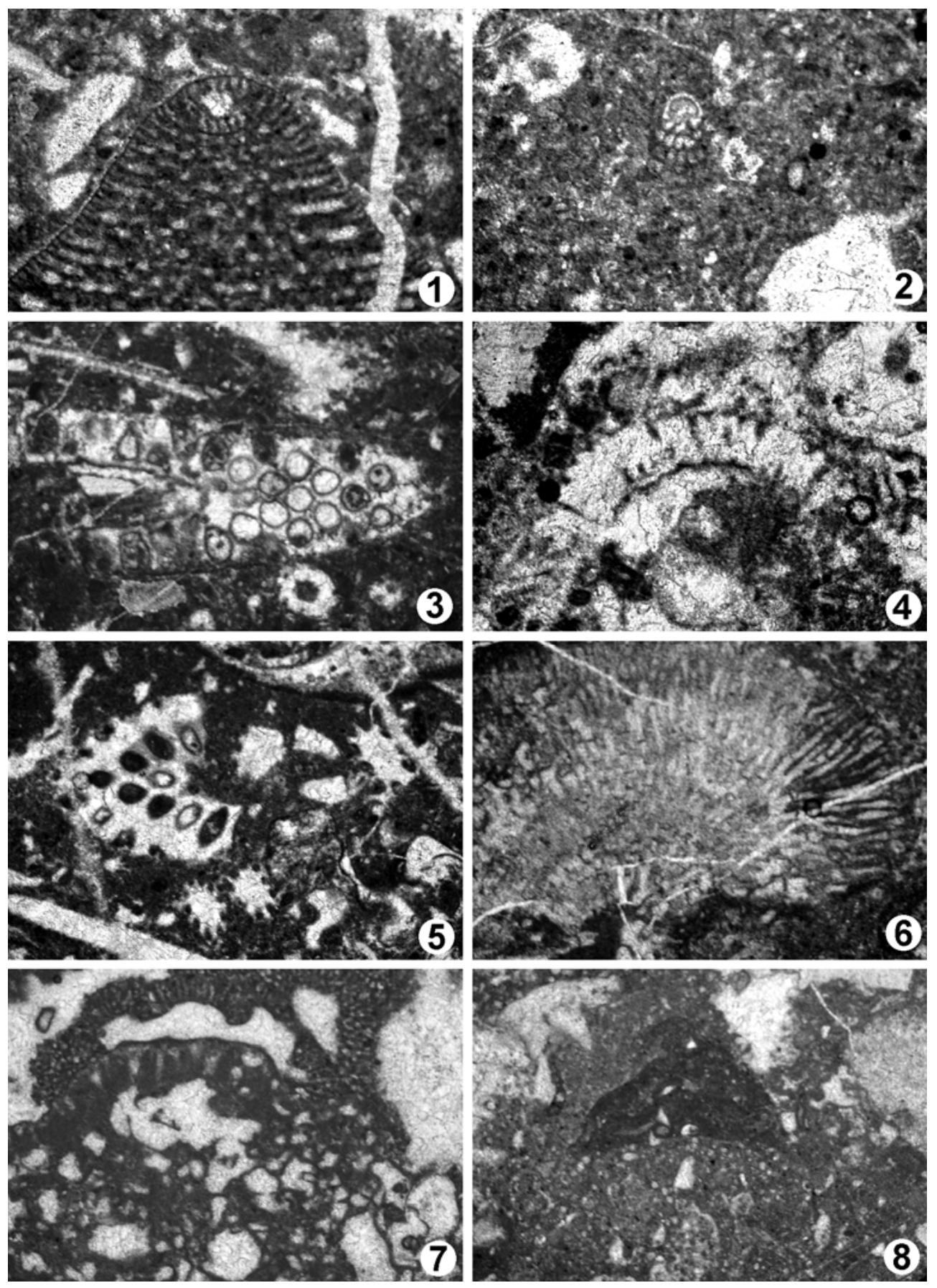
Plate II
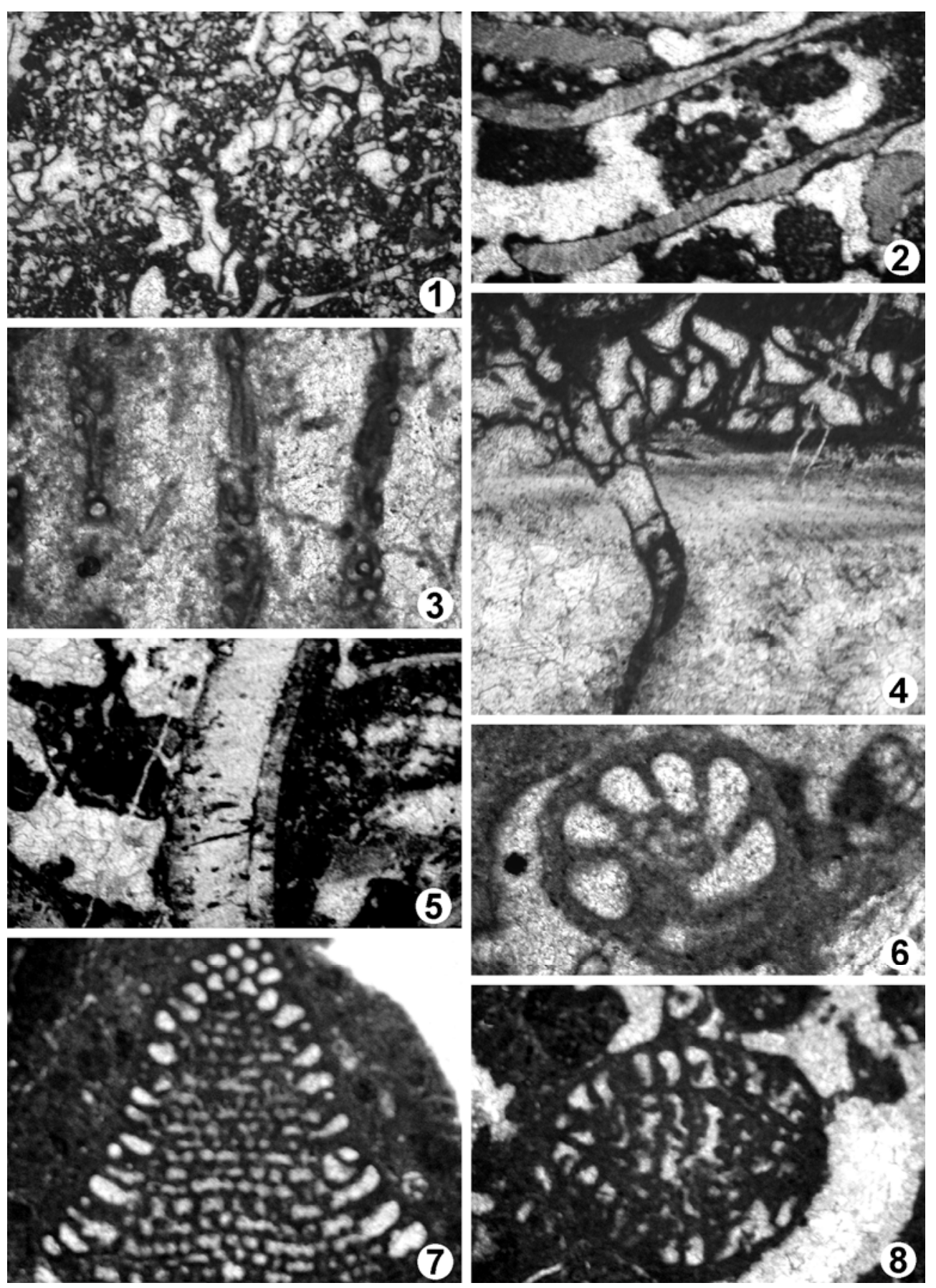
Plate III
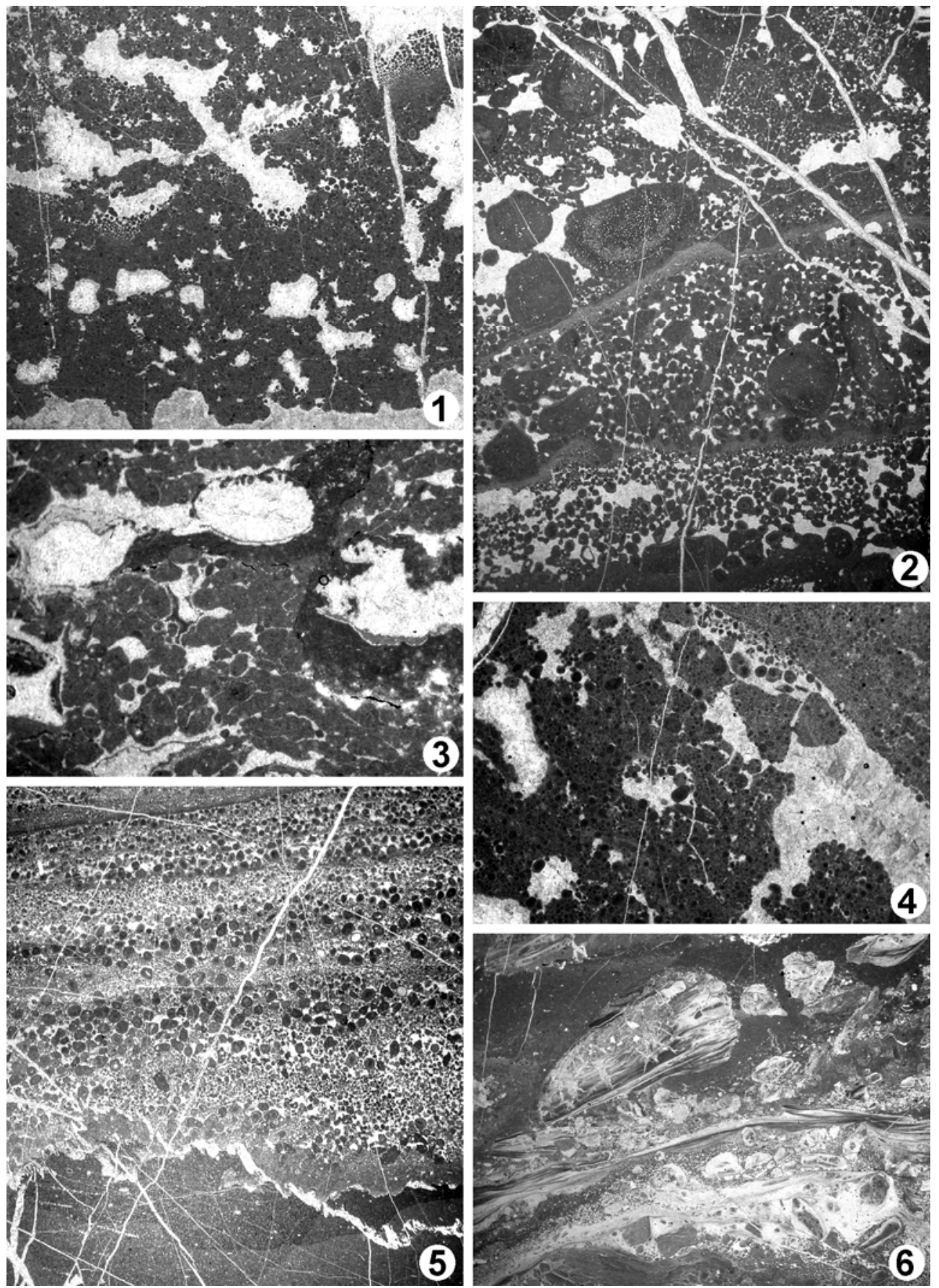
Plate IV

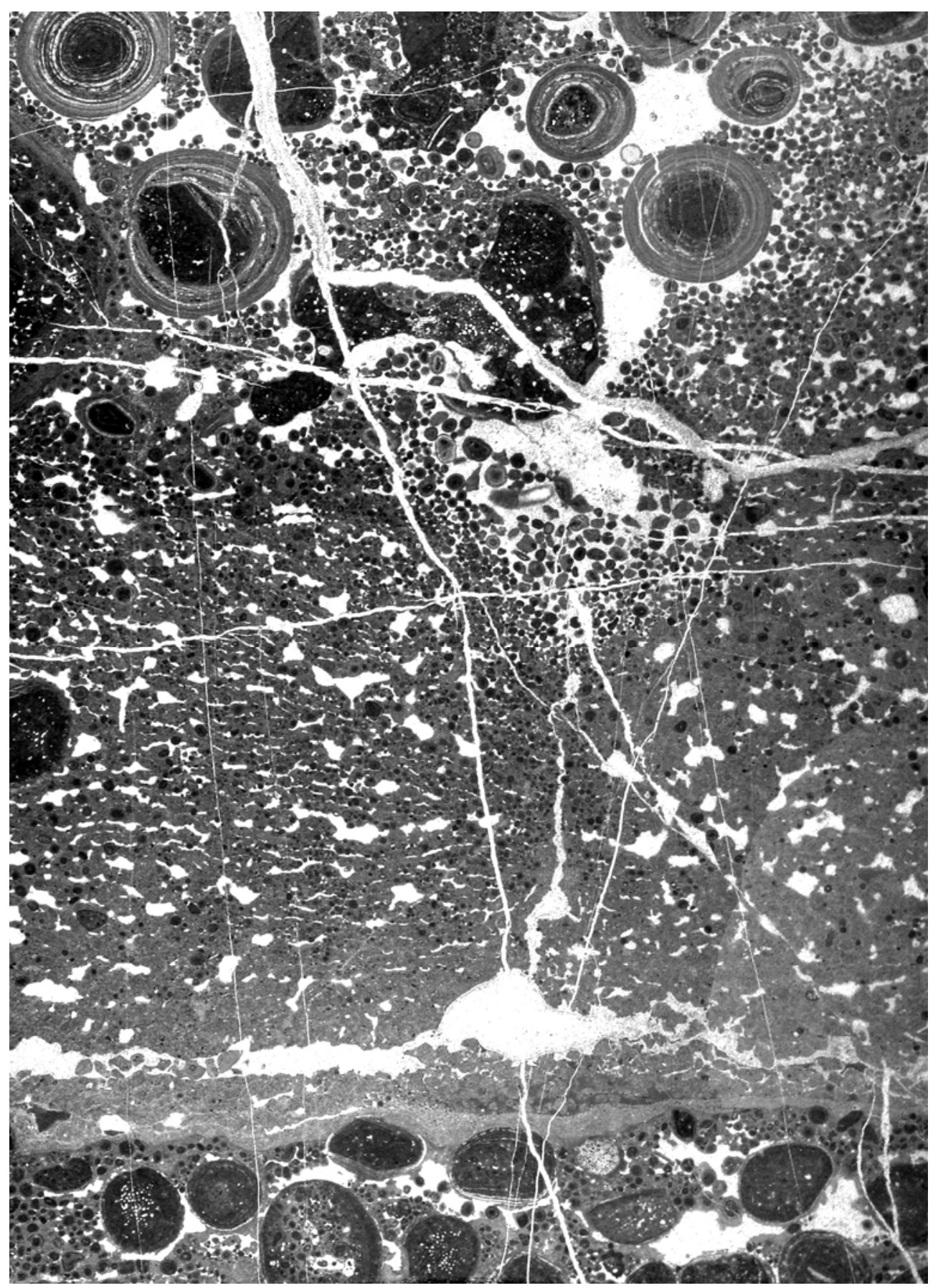

